\title{
Organizational readiness for the digital transformation: a case study research
}

\section{Marisa Analía Sánchez}

Doctorate degree in Computer Science from Universidad Nacional del Sur in Bahía Blanca, Argentina. She is currently Associate Professor of graduate and post-graduate courses at Department of Management Sciences at Universidad Nacional del Sur, Argentina mas@uns.edu.ar

Juana I. Zuntini

Master degree in Business Administration from Universidad Nacional del Sur in Bahia Blanca, Argentina. Owner of Zuntini Soluciones Integrales (technology company). She is currently a Teaching Assistant at Department of Management Sciences at Universidad Nacional del Sur, Argentina jzuntini@uns.edu.ar

Editor Científico: José Edson Lara

Organização Comitê Científico

Double Blind Review pelo SEER/OJS

Recebido em 17.02.2018

Aprovado em 16.04.2018

\footnotetext{
(c) (1) (5)

Este trabalho foi licenciado com uma Licença Creative Commons - Atribuição - Não Comercial 3.0 Brasil
}

\section{Abstract}


The world is changing profoundly and it has gone from the industrial age to the era of intelligent and connected products with consequences both in organizations and society. The aim of this research work is to formulate a framework that explains resources, capabilities and management choices necessary to respond to the new environment. The scope is on small and medium sized established companies. The research methodology is based on literature review and an in-depth case study based on three enterprises. The framework describes (a) external forces in the context of emergent technologies; (b) adequate strategies arising from a value chain analysis; (c) resources and capabilities of critical importance. The framework contributes to the comprehension of how small and medium size companies respond to the digital transformation process.

Keywords: Digital transformation; digital strategy; The Five Competitive Forces Model; Value Chain Analysis; Dynamic capabilities; Ecosystem theory.

\section{Preparação organizacional para a transformação digital: uma pesquisa de estudo de caso}

\section{Resumo}

O mundo está mudando profundamente e passou da era industrial para uma era de produtos conectados e inteligentes, o que causa impactos nas organizações e na sociedade. $\mathrm{O}$ objetivo deste trabalho de pesquisa é formular uma estrutura que explique recursos, capacidades e escolhas de gerenciamento necessárias para responder ao novo ambiente. São consideradas organizações estabelecidas e de pequeno ou médio porte. A metodologia da pesquisa baseia-se na revisão da literatura e em um estudo de caso detalhado com base em três empresas. O framework descreve (a) forças externas no contexto das tecnologias emergentes; (b) estratégias adequadas decorrentes de uma análise de cadeia de valor; (c) recursos e capacidades relevantes na era digital. A framework contribui para a compreensão de como as pequenas e médias empresas respondem ao processo de transformação digital.

Palavras-chaves: Transformação digital; estratégia digital; $\mathrm{O}$ Modelo das Cinco Forças Competitivas; Análise de Cadeia de Valor; Capacidades dinâmicas; Teoria do ecossistema. 


\section{Preparación organizacional para la transformación digital: un estudio de} casos

\section{Resumen}

El mundo está cambiando profundamente y ha transitado de la edad industrial a una era de productos conectados e inteligentes y las consecuencias impactan en las organizaciones y la sociedad. El objetivo de este trabajo de investigación es formular un marco conceptual para entender los recursos, capacidades y decisiones gerenciales necesarias para responder al nuevo ambiente. Se consideran organizaciones establecidas y de tamaño pequeño o medio. La metodología de la investigación está basada en una revisión de la literatura y un estudio de casos en profundidad basado en tres empresas. El marco describe (a) las fuerzas externas en el contexto de las tecnologías emergentes; (b) estrategias adecuadas que surgen del análisis de la cadena de valor; (c) recursos y capacidades relevantes en la era digital. El marco contribuye a la comprensión de cómo pequeñas y medianas empresas responden al proceso de transformación digital.

Palabras clave: Transformación digital; estrategia digital; Modelo de las Cinco Fuerzas Competitivas; Análisis de la Cadena de Valor; Capacidades dinámicas; teoría de Ecosistemas.

\section{Introduction}

The impact of the digital revolution derives from the extraordinary progress of technology and the opportunity for technology deployments to spread throughout the world. This is a time when technologies are demonstrating that they can do work that we have never thought of as pre-programmed or routine (McAfee \& Brynjolfsson, 2017). Hundreds of millions of people started to have powerful, flexible, and connected computers with each other at all times. Moore's law -the steady doubling in integrated circuit capability every eighteen to twenty-four months- is still going strong. Big data, analytics, and artificial intelligence affect business processes and how decisions are taken; social networks shapes customers' interactions and consumptions; mobile apps and cloud computing are essential to deliver services; the Internet of Things (IOT) connects products through sensors and software giving more opportunities to create value or reduces costs; robots, drones, and 3D printing are key drivers of the evolution of supply chain (Venkatraman, 2017). Embedded sensors, processors, software, and connectivity in products, coupled with a product cloud in which product data is stored and analyzed and some applications are run, are driven dramatic improvements in 
product functionality and performance (Porter \& Heppelmann, 2014). Smart products can monitor usage and customer satisfaction and represent an opportunity for creating new business models that change the focus from independent products to offers based on services.

Software innovations are available for free. Tech giants including Microsoft, Amazon, Google, and IBM have made their internally developed machine learning technologies available to other companies via a combination of the cloud and application programming interfaces (McAfee \& Brynjolfsson, 2017). Also, the cost of buying storage and computing power from giants can be less than running a data centre. Hence, even small companies can take the opportunities given by technology. However, they should adapt their business models or processes and then the research question of this work emerges: which factors and resources are relevant to an organization's preparedness to respond to the digital challenge. Sánchez (2017) provides a theoretical framework that explains the resources, capabilities, management choices and challenges necessary to respond to the new environment. While some model's constructs and propositions may be valid for any organization, given the nature of the problem it is necessary to make exploratory studies to understand the local environment, barriers, and critical success factors to generate value from technology. This work builds on previous research and on the analysis of three cases. This paper will contribute to existing knowledge by considering relevant issues to digital readiness, and by providing actionable prescriptions for practitioners that are grounded in the empirical reality of the strategies and actions of the considered organizations. The scope is on small and medium size established companies.

The article is organized as follows. Section 2 describes the methodology. Section 3 provides a literature review that provides the theoretical lens to conduct the case studies. Sections 4,5 and 6 are devoted to present the cases. Finally, a discussion and conclusions are provided.

\section{Methodology}

The case research methodology based on semi-structured interviews is used for this study. The research questions are "how" and "why" questions that seek to understand the local environment, barriers, and required conditions to generate value 
from technology. Based on the research question, the requirements for the case selection were: the case organization must be a for profit enterprise; the direction should be settled in the region (i.e. should not be an international corporation which management is dependent on non-local environment and factors); and the product (or service) delivered and/or the processes should exhibit a minimal level of digitalization. Research access was negotiated and granted before the interviews.

Based on the literature review, a set of themes and dimensions that formed the theoretical lens were identified. This conceptualization pertinent to the phenomenon under study is the baseline to define a questionnaire to guide the interviews. Although the questions were not open-ended, time was given to the interviewees to discuss the proposed topic and add all the information that considers relevant. The findings are supplemented with newspapers' articles and information from the organization's website. Data analysis was then carried out by moving back and forth between empirical data, the theoretical lens, relevant literature and the emerging model (Eisenhardt, 1989). At this stage, the aim was to assess how the empirical findings corroborate or differ from the adopted theoretical lens.

\section{Literature review}

In this work, the term digital technologies is used to refer to key technologies that have had great impact on society and organizations: mobile technologies, social media, cloud technology, big data analytics, the internet of things and artificial intelligence. Each of these technologies has value on its own right but when organizations bring digital technology into their business models -the core way their deliver value to customers -their business value start multiplying (Libert, Beck, \& Wind, 2016). However, established companies do not always understand they current business model well enough to know if it would suit a new opportunity or hinder it. The exploratory research presented in this work is primarily based on the conceptualization that explains the resources, capabilities, management choices and challenges necessary to respond to the new environment presented by Sánchez (2017). The proposal is based on the frameworks and theories of private sector: Michael Porter's Five Competitive Forces and Value Chain Analysis frameworks, Resource-based View of the Firm and Dynamic Capabilities, and Ecosystem theory. In what follows, a brief 
introduction of the proposal is provided in order to understand the significance of digital transformation and make the paper self-contained. The description is extended with additional references.

\section{a. Five Forces Model Analysis}

Regarding the digital transformation, Porter and Heppelmann (2014) argue that although the loT shows a new set of technological opportunities, the rules of competence and competitive advantage remain the same. Smart, connected products capture usage data that allows segmenting customers, customizing products, setting prices to better capture value, and extending value-added services (Porter \& Heppelmann, 2014). Organizations that focus on customer success and experience are more prepared to enhance differentiation. As a consequence, rivalry may shift away from price. Also, this serves to mitigate buyers' bargaining power. However, smart, connected products can increase buyer power by giving buyers a better understanding of true product performance.

Smart, connected products often introduce powerful new suppliers such as providers of sensors, software, connectivity, embedded operating systems, data storage, and analytics (Porter \& Heppelmann, 2014). The high fixed costs of more complex product design and embedded technology can raise barriers to entrants. On the other hand, the bargaining power of these new suppliers may be reduced by creating relationships with other providers that offer complimentary services. The capability of an organization to develop in house or build a partnership with technology experts may give the advantage of first-mover by collecting and accumulating product data.

The trend of including new capabilities results in products becoming part of a broader product system and this increases the threat of new entrants. In many industries, smart, connected products create new types of substitution threats. To understand how digitization is affecting an organization, Weill and Woerner (2015) proposes to assess the digital threat by thinking in terms of one of the best-selling product or service and evaluate to what extent it is delivered digitally or can be augmented with valuable information. 
Regarding rivalry, some authors discussed the concept of coopetition -that is cooperation between competitive organizations (Bengtsson \& Raza-Ullah, 2016), (Bradshaw \& Palmer, 2010). The term was conceptually established several years ago but with the emergence of digital transformation relationships among companies are redefined. Coopetition is at the core, pulling and pushing different patterns of relationships between incumbents and digital giants, between incumbents and tech entrepreneurs, and between digital giants and entrepreneurs (Venkatraman, 2017).

\section{b. Value Chain and Value System Analysis}

Porter and Heppelman (2015) analyze how the nature of intelligent and connected products affects the value chain. For example, with smart, connected products design processes should accommodate to achieve hardware standardization through software-based customization, enable personalization and predictive, enhanced or remote service. IoT products generate huge amount of data that may be used to improve product or service design, marketing and after-sale service. Smart, connected products create the need for robust security management to protect the data flowing to, from, and between products, and secure access between the product technology stack.

Even though digital technologies pose some opportunities, there are uncertainties about the market needs and hence which is the right value proposition to develop. There are no clear rules about how to proceed. Slama et al. (2015) suggest building a minimum viable product and get to market fast. Hence, firms have first-mover advantages by collecting and accumulating product data and using it to improve product and services. A first-mover strategy may imply shorter development cycles and a strategy to optimize development may be adopting agile methodologies. A detailed description may be found elsewhere (Sánchez, 2017). As a synthesis it may be concluded that smart, connected products require new capabilities across the activities of the value chain such as technology savviness, data analytics, integrating teams with varied work styles, agile project management, among others. 


\section{c. Resources and dynamic capabilities to adopt a digital strategy}

According to the resource-based view of the firm the origins of competitive advantage are valuable resources (or competences) that firms possess, which are often intangible assets such as skills or reputation (Penrose, 1959). The concept of dynamic capabilities refers to the firm's ability to build, integrate, and reconfigure internal and external competences to address rapidly changing environments (Teece, Pisano, \& Shuen, 1997). The aim of this section is to summarize the required resources and capabilities for a company to benefit from new technologies.

With the incremental production of data, the management, governance, analysis, and security of data are developing into a major new business function. Porter describes a new organizational structure including a new functional unit focused on data management (Porter \& Heppelmann, 2015). McAfee and Brynjolfsson (2012) also consider the phenomenon of Big Data and analytics (the recent explosion of digital text, pictures, sounds, videos, sensor readings) and how it transformed decision making. The authors describe management challenges related with leadership, talent management, technology, decision making and culture. Companies need leaders who can spot a great opportunity, understand how a market is developing, think creatively and propose truly novel offerings, articulate a compelling vision, persuade people to embrace it and work hard to realize it, and deal effectively with all stakeholders. Organizations require expertise at working with large volume of data and also capability of helping leaders reformulate their challenges in ways that big data can tackle. It is also necessary to increase cooperation between the people who understand the problems and the ones who master problem-solving techniques and can generate value from data. Successful information technology organizations will train and recruit people with a new set of skills who can integrate analytic capabilities into their production environments (Davenport, Barth, \& Bean, 2012). Some authors also discuss the leadership challenges posed by digital transformation. For example, a data-driven decision making poses managerial challenges related with how decisions are made and who gets to make them (Klotz, 2016). Bennis (2013) argues that 
information-driven transparency will change the way that power is delivered by top leaders, and that leaders need to embrace that transparency.

Finally, Ross et al. (2016) findings include the importance of developing a digital strategy and the need of an operational backbone that ensures efficient, reliable transactions and customer interactions.

\section{d. Digital ecosystem research}

The digital ecosystem theory is also adequate to analyze the role of information technology in organizations that operate in complex networks and has its origins in complexity theory (Stacey, 1995) and organizational ecology (Hannan \& Freeman, 1977). Business ecosystems are networks of organizations that are held together through formal contracting and mutual dependency. On the online world, the concept of ecosystem is related with the recent appearance of platform businesses such as Amazon, Uber, Airbnb or eBay that are disrupting the established incumbents in their industries. Platforms are online environments that take advantage of the economics of free, perfect, and instant (McAfee \& Brynjolfsson, 2017). McAfee and Brynjolfsson (2017) observe that the important attributes of information goods are free (once something has been digitalized, it's essentially free to make and additional copy of it), perfect (a digital copy is exactly identical to the original identical version) and instant (networks allow distribution of a free, perfect copy of information goods from one place to another virtually immediatly).

Platforms comprise four types of players enabling value-creating interactions. The owners of the platforms control their intellectual property and governance (Google owns Android). Providers serve as the platforms' interface with users (mobile devices are providers on Android). Producers create their offerings (for example, apps on Android), and consumers use those offerings (Van Alstyne, Parker, \& Choudary, 2016). And when a platform is opened up to allow outside contributions, demand for the owner's product goes up as others contribute complementary goods. Co-creation refers to the scenario in which individuals or consumer communities produce marketable value in voluntary activities conducted independently of any established organization, although they may be using platforms provided by such organizations (Karhu, Botero, Vihavainen, Tang, \& Hämäläinen, 2011). Libert et al. (2016) observes 
that network leaders ask what value their customers and other networks have to offer, and see the value in customer co-creation, advocacy, and sharing.

\section{Table 1}

Summary of emerging dimensions arising from literature review

\begin{tabular}{|c|c|c|}
\hline Emerging dimensions & Main references & $\begin{array}{l}\text { Related } \\
\text { questions }\end{array}$ \\
\hline \multicolumn{3}{|l|}{ Five Forces Model } \\
\hline $\begin{array}{l}\text { Strength of consumers high } \\
\text { because they know true } \\
\text { product performance. Digital } \\
\text { transformation increases } \\
\text { customer expectations on } \\
\text { quality of service. This } \\
\text { suggests customer-centric } \\
\text { solutions. }\end{array}$ & $\begin{array}{l}\text { (Porter and } \\
\text { Heppelmann, } \\
\text { 2014) }\end{array}$ & $2,3,7$ \\
\hline $\begin{array}{l}\text { Strength of technology suppliers } \\
\text { increases bargaining power. }\end{array}$ & $\begin{array}{l}\text { (Porter and } \\
\text { Heppelmann, } \\
\text { 2014) }\end{array}$ & 1 \\
\hline Talent in data analytics. & $\begin{array}{l}\text { (Porter \& Heppelmann, } \\
\text { 2014), (Porter \& } \\
\text { Heppelmann, } \\
\text { 2015) }\end{array}$ & 1,8 \\
\hline Technology savviness. & $\begin{array}{l}\text { (Porter \& Heppelmann, } \\
\text { 2014), (Porter \& } \\
\text { Heppelmann, } \\
\text { 2015) }\end{array}$ & 1,7 \\
\hline Partnership with ITC experts. & $\begin{array}{l}\text { (Porter \& Heppelmann, } \\
\text { 2014) }\end{array}$ & 1 \\
\hline Digital threat (substitutes). & $\begin{array}{l}\text { (Weill and Woerner, } \\
\text { 2015) }\end{array}$ & 6 \\
\hline
\end{tabular}

\section{Value Chain Analysis}

Agile methodologies.

(Conforto, Salum, 9-12

Amaral, da Silva, \&

Magnanini de

Almeida, 2014),

(Porter \&

Heppelmann, 2014)

Talent in data analytics.

(Davenport, 2014), 2, 7, 8

(Porter and 


\begin{tabular}{|c|c|c|}
\hline & $\begin{array}{l}\text { Heppelmann, } \\
\text { 2014) }\end{array}$ & \\
\hline Collaborative culture. & $\begin{array}{lr}\text { (Conforto, } & \text { Salum, } \\
\text { Amaral, da } & \text { Silva, \& } \\
\text { Magnanini } & \text { de } \\
\text { Almeida, } & 2014), \\
\text { (Porter } & \text { \& } \\
\text { Heppelmann, } \\
\text { 2014) }\end{array}$ & $9-12$ \\
\hline \multicolumn{3}{|l|}{$\underline{R B V \text { and Dynamic Capabilities }}$} \\
\hline Talent in data analytics. & $\begin{array}{l}\text { (Porter \& Heppelmann, } \\
\text { 2014), (McAfee \& } \\
\text { Brynjolfsson, } \\
\text { 2012), (Davenport, } \\
\text { Barth, \& Bean, } \\
\text { 2012) }\end{array}$ & $2,7,8$ \\
\hline Leadership. & $\begin{array}{l}\text { (McAfee } \\
\text { Brynjolfsson, } \\
\begin{array}{l}\text { 2012), } \\
\text { 2013), }\end{array} \text { (Bennis, } \\
2016)\end{array}$ & 4,13 \\
\hline Clear strategy. & $\begin{array}{c}\text { (Ross, Sebastian, \& } \\
\text { Beath, 2016) }\end{array}$ & $2,4,5,13$ \\
\hline Operational backbone excellence. & $\begin{array}{c}\text { (Ross, Sebastian, \& } \\
\text { Beath, 2016) }\end{array}$ & 13 \\
\hline \multicolumn{3}{|l|}{ Ecosystem theory } \\
\hline $\begin{array}{l}\text { Partnerships with stakeholders. } \\
\text { Collaboration with suppliers, } \\
\text { partners, } \\
\text { competence, and government. }\end{array}$ & $\begin{array}{l}\text { (McAfee } \\
\begin{array}{l}\text { Brynjolfsson, } \\
\text { 2017), } \\
\text { Alstyne et } \\
\text { 2016) }\end{array} \text { al., } \\
\end{array}$ & 1,7 \\
\hline Co-creation. & $\begin{array}{l}\text { (Libert, Beck, \& Wind, } \\
\text { 2016) }\end{array}$ & $1,4,10-12$ \\
\hline
\end{tabular}

Source: Own elaboration.

Table 1 summarizes the set of themes and proposed dimensions. They are mainly based on the framework and previous research of Sánchez (2017). The conceptualization is the baseline to the questionnaire used to conduct the interviews and proposed by Sánchez. Questions are used as the starting point to introduce and discuss a topic. What follows is a presentation of how three companies are responding to the digital transformation. The first is characterized by the entrepreneurial spirit of 
the owner that encourages being open to change and innovation. Other is focusing on digitizing core operations rather than more creative digital innovations. The last one is moving proactively to get a footing in the new digital opportunities and capitalizing on the benefits of incumbency.

\section{Case study "Gen Tecnológico"}

Research access was negotiated and granted in June 2017. A face to face interview with the director of the organization was conducted. Information was supplemented by newspapers' articles and information from the organization's website. To represent the evolution of the organization to current digital maturity, a timeline of the key events, activities and decisions that emerged at the organization with regard to the phenomenon of interest was constructed.

Gen Tecnológico is a division of Tech as Service S.R.L. settled in Buenos Aires and Bahía Blanca. The organizational structure includes three business units (Gen Tecnológico, 2017). The "Impresión" unit offers solutions through all the printing value chain, including equipments, services, and recycled cartridges for laser and labeling printers. Recycled cartridges are manufactured under quality standards ASTM 1856 and 2036, and ISO 9000. The "Todo Rotuladoras" unit becomes the first multi-brand supplier of industrial labeling equipments and supplies in the country, and imports, delivers and manufactures products. The "Tecnología" unit develops technological projects, and offers consulting and auditing services. Customers come from private and public sectors: municipal governments from Buenos Aires province, judicial system, Jotafi Computación Interactiva S.A. (main printing supplies consumer of the city), and Newen Ingeniería (a partner that also participates in industrial projects). The company has a policy of protection of the environment by which the entire production process is designed with the idea of minimizing waste. They also have a policy of occupational safety and health, seeking that all processes are executed on the basis of continuous improvement, encouraging the participation of all members of the organization in the detection of opportunities. There is a commitment to growing in the development of new and better solutions in the aforementioned sectors. 


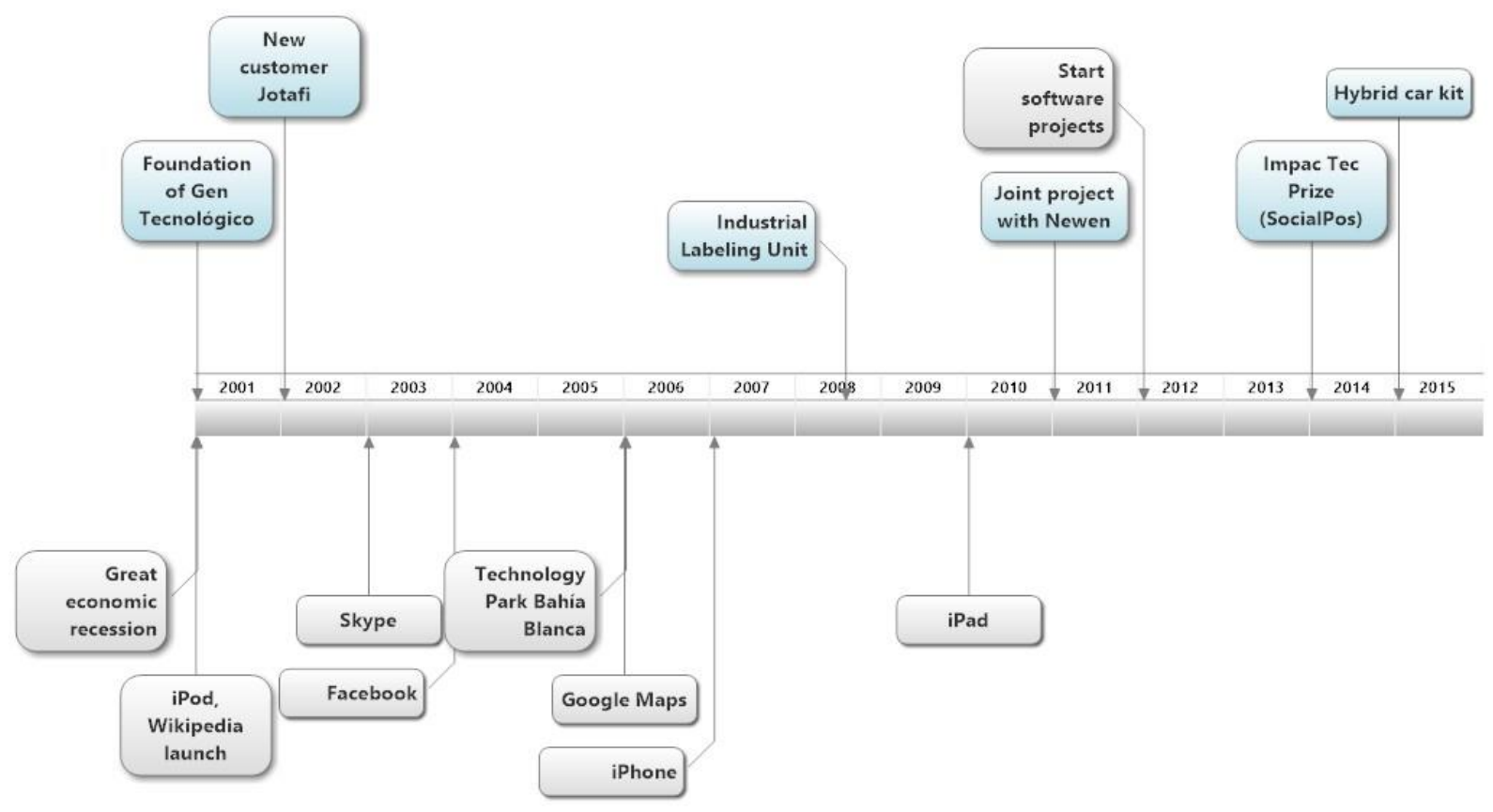

\section{Figure 1}

Timeline of Gen Tecnológico

Source: Own elaboration.

Figure 1 aims to synthesize the main events, activities and organizational decisions that contributed to the preparation to adopt new technologies. In addition, events that enable contextualizing the evolution of the company in time are included. The company was settled in 2001. That year was the scene of a serious economic and political crisis during which the national currency was devalued by hampering the purchase of imported products. In this way, the market for recycled products is increased. In 2002 the company started building a relationship with one of its main customers by then (Jotafi S.R.L.). In 2009, they incorporate products of professional and industrial labelling in view of the decline of the toner recycling business. Despite the restrictive general policies, the entry of Chinese alternative products was never prevented. The entrepreneurial spirit of Gen Tecnologico's founder Leonardo Valente is reflected in the awards received. In March 2014, he won the ImpacTec innovative technology contest with the SocialPOS project. SocialPOS is an open web-based platform aimed to the inclusion of businesses in poor neighbourhoods with a nonbanking social cards (Berenstein, 2014), (La Nación, 2014). This technology connects to a smart phone via a very cheap device that transforms the information in the card bandwidth into a readable number for any Android device. In this way, businesses that do not have a POS terminal (Point of Sale) are included. In August 2014 in Singularity 
University together with the Mexican Javier Rincón and Christian Henríquez from Chile, they founded Exponential Motor Company, a company with the mission of developing and selling technology that allows converting some cars into an hybrid at a moderate price (La Nación, 2015), (Diario La Nueva S.R.L., 2015). They developed a device that is installed in a few hours on the wheels to harness the kinetic energy of braking. Valente and his team transformed its first hybrid in Argentina in April 2015 to assemble their kit in a Peugeot Partner of the Department of traffic of the city of Buenos Aires (Argentina Autoblog, 2015). In 2016 a Fontar subsidy granted by the government of 1.3 million pesos was approved which allows to continue the product development (in prototype stage).

Since 2012 the company is involved in some software projects. For example, Riskos is a tool for managing corporate risks created on the basis of the risk methodology of the IAE Business School Center and implemented at Profertil (a company that offers production and wholesale commercialization of nitrogen fertilizers in the Southern Cone). Meetit is an application for staff recruitment and selection based on pre video interviews. LivePanel, currently in the process of expansion throughout Latin America, is a technology of measurement of public opinion through mobile phones. Through its participation in the Polo Tecnológico (civil association integrated by the municipal government, local universities and technology companies) (Polo Tecnologico del Sur, 2018), the company is connected with other regional technology developers, giving rise to Innobattery S.A. (2016), a company that designs and manufactures batteries based on hybrid ultra capacitors.

The following sections will examine the company's readiness for digital transformation by examining data obtained from an interview conducted with the owner (a summary of responses is included in the Appendix).

Strategy. The owner agreed on that the value proposition depends on new forms of collaboration with partners, suppliers and internal customers, and dependency relies less on customers. The projects described in the previous section illustrate the awareness of the importance of understanding the dependence on different stakeholders both from the private and public sector. When asked about the strategy definition, the interviewee agreed on that process and business model transformation and data analytics for innovation are part of the strategy. Although improving customer 
experience and data analytics for decision making are also taken into account, they are not considered critical. The General Director, consultants and specific area employees are responsible for defining the digital strategy. The main drivers to define an ICT initiative are organizational culture and the seeking of new commercialization channels. As stressed by the owner, innovation is part of their daily way of working.

Resources and capabilities. Current projects are making extensive use of digital technologies such as mobile, social networks, cloud computing and data analytics. The organization works on developing the required technology savviness. Currently, less emphasis is given to customers' needs monitoring. Based on the dialogue with the interviewee, and considering the organization's projects, the initiative and leadership of the owner emerges as a strong capability. Leadership has allowed identifying opportunities, define innovative proposals and interact with stakeholders.

Data management. When discussing data management, the interviewee agreed on that managers regularly consider opportunities that data analytics may bring to the organization and they are working on the integration of data from multiple internal sources. They also identify internal opportunities for big data by evaluating processes, strategies and citizens' needs. On the other hand, they are not working on data integration from external sources, data sharing with stakeholders or explored tools to process unstructured data such as text, video or images.

Project management. The interviewee manifested that the success of a project not only depends on traditional criteria such as time, budget and specifications compliance but that the quality and usefulness of the solutions are a constant concern. The stakeholders participate in project's reviews and suggestions are taken into account during design. Responsibility for project planning is collaborative, which is an indication of the incorporation of the concept of collaborative work.

Barriers that limit technology adoption. Respondent was provided with a list of 15 possible barriers and was asked to select at most three. He selected "Many priorities that compete" and "Satisfaction with status quo".

\section{Case "Argentina Crossing S.A."}


Research access was negotiated and granted in June 2017. The Financial Manager and a Financial Adviser participated in the interview. Information was also retrieved from the organization's website. Argentina Crossing SA is a consulting firm founded in 2003 with the aim of providing financial advice to both people and organizations throughout the country (Argentina Crossing S.A., 2017). A defining characteristic of the firm is the focus on customers and recognition of the customer's role in service creation and delivery. The organization offers advice on investments, insurance and pensions. The team is composed of economists, certified public accountants, and graduates in business administration with extensive industry knowledge and experience.

Strategy. The value proposition of the organization depends heavily on collaboration with providers of financial products and services. The collaboration allows commercializing new products, modifying existing ones, or updating traditional products. One of the core concerns of the organization is the customer; therefore, improving the customer experience is part of the strategy. Some decisions are based on data analysis. For example, both the evaluation of advisers' and organizational performance is based on data derived from the software used by each adviser and the group leaders, and from management reports. Process transformation is part of the strategy since its improvement is a matter of concern. Both of the interviewees agreed on that they know very well customers' needs. This is consistent with consultants' recruitment criteria: selection of professional financial advisers who know the cultural roots of customers. Middle management is responsible to define the digital strategy. Motivations for technology-based initiatives include the customers' expectations, pressure from partners and suppliers, the maturity of other companies, and organizational culture. One of the services that had received major innovations is customers' service: all transactions are performed from a digital platform.

Resources and dynamic capabilities. Respondents indicated that they are using digital technologies such as social networks (Facebook and Linkedin), mobile, cloud computing and data analysis. Employees and managers analyze data generated by internal systems; and data is integrated with data from other sources. However, big data analysis and data mining are not part of the organizational capabilities. 
Project management. With respect to project management, respondents considered success is based on traditional criteria such as time, budget and requirement fulfilment. Also, they agreed on that quality and usefulness of the solution are key requirements that define the success of a project. A systematic procedure in which stakeholders participate with influence in the development of a project is not perceived. Anyway, in some projects such as the development of on-line training for financial advisors, stakeholders participated with influence in development.

Barriers that limit technology adoption. Respondents selected "Security issues (data, digital signature, etc.)", "Legal and regulatory restrictions", and "Many priorities that compete".

\section{Case "Etman Distribuidor Nacional de Autopartes"}

The case is based on a supplier of auto-parts represented throughout the country. There are three distribution centres and three branches in different parts of the country. For more than 56 years the founders have proposed as an objective the permanent search for excellence in service. Institutional description provided on the web site of the company highlights two axes: (a) innovation and technology, and (b) human capital. Innovation and technology is apparent in the market monitoring and the constant update of information systems supporting processes. Human capital is reflected in efforts to provide continuous employee training and development. The customers are mainly auto-parts distributors.

On its web site the company publishes a catalogue of more than 730,000 products organised in 26 systems (related with automotive systems) to facilitate products' search (Mundo Aftermarket, 2017). In addition, for each product there is technical information, recommendations, installation, guarantees and videos (Etman Distribuidor Nacionall de Autopartes, 2017). The data organization and updating is the result of a mature knowledge management and shows how the company provides services that enhance the customer experience and satisfaction. The company has a warehouse management system especially developed for the management of its stores with the objective of optimizing spaces as well as the process of reception of orders. In addition, it has a dispatch automation system (Mundo Aftermarket, 2017). 
In Etman they understand that growth will be given with that of its clients and thus they provide high profit margins, speed of delivery and management tools. The company has a presence on Facebook, Twitter, Linkedin, Google + and Youtube. Through these channels, it implements an effective multi-channel strategy.

The following section will examine the company's readiness for digital transformation by examining data obtained from an interview conducted with managers from Digital Tools, Systems and Marketing areas. Research access was negotiated and granted in September 2017.

Strategy. The organization understands that the value proposition depends on new forms of collaboration with suppliers and customers, and dependency relies less on partners, government and competency. When asked about the strategy definition, the interviewee agreed that improving customer's experience, process and business model transformation and data analytics for innovation and decision taking are part of the strategy. They also consider that they know customers' needs. The upper and middle management are responsible for defining the digital strategy. The main drivers to define an ICT initiative are customers' expectations and the seeking of new commercialization channels. One of the most innovative services is a digital catalog available for customers (distributors). It is a powerful tool designed to speed commercial transactions, request budgets, real time stock checking and on-line orders. Resources and capabilities. Current projects are making extensive use of digital technologies such as mobile, social networks, cloud computing and data analytics. The organization works on developing the required technology savviness and also builds partnerships with technology incumbents. Etman saw that it was vulnerable to auto parts sellers that were offering product through on-line platforms such as MercadoLibre. In an effort to meet the challenge and taking into account that Etman does not aspire to engage in direct selling, the company developed a software platform to be used by its distributors. The software allows distributors an easy publication of products on an on-line e-commerce platform (e.g. MercadoLibre). The project is a joint effort with a technology incumbent that assures technical savviness and experience in similar developments. It is interesting to note that the solution redefines MercadoLibre's role of competitor to supplier. 
Data management. When discussing data management, the interviewee agreed on that they are working on the integration of data from multiple internal and external sources, and data sharing with stakeholders. On the other hand, they are not working on big data o exploring tools to process unstructured data such as text, video or images.

Project management. The interviewee manifested a clear idea that the success of a project not only depends on traditional criteria such as time, budget and specifications compliance but that the quality and usefulness of the solutions are constant concern. Stakeholders participate in project's reviews and suggestions are considered in design. Responsibility for project planning is collaborative, which is an indicator of the incorporation of the concept of collaborative work.

Barriers that limit technology adoption. Respondents were provided with a list of 15 possible barriers and were asked to select at most three. They selected "Many priorities that compete" and "Security issues (data, digital signature, etc.)". They also observe that the degree of adaptation of customers (distributors) to technology innovation may limit the use of digital services (such as the digital catalog).

\section{Discussion}

By integrating the dimensions derived from the literature review and the findings from the case studies, a framework of digital readiness in small to medium companies can be derived. As the proposal suggests the path for digital transformation depends on a number of external and internal conditions. The framework aims to assess organizational readiness for creating value within the new environment. Figure 2 summarizes the main components of the framework.

The external analysis highlights strength of technological suppliers, the power of customers with increasing expectations of quality of service, the digital opportunities that may threat traditional products or services, and the emergence of cooperation between competitive organizations.

Digital platforms are the drivers of many most successful companies and set the stage for collaboration and cooperation among different stakeholders. In the case of Etman, the organization assumes the role of leader by providing distributors the platform for e-commerce operations. The company understands that good design 
depends on the requirements and users' opinions, and the value will be given if the majority of distributors use it. The case reflects how the company understands the importance of B2B digitization, and of including network effects in its business models. It also works collaboratively with distributors.
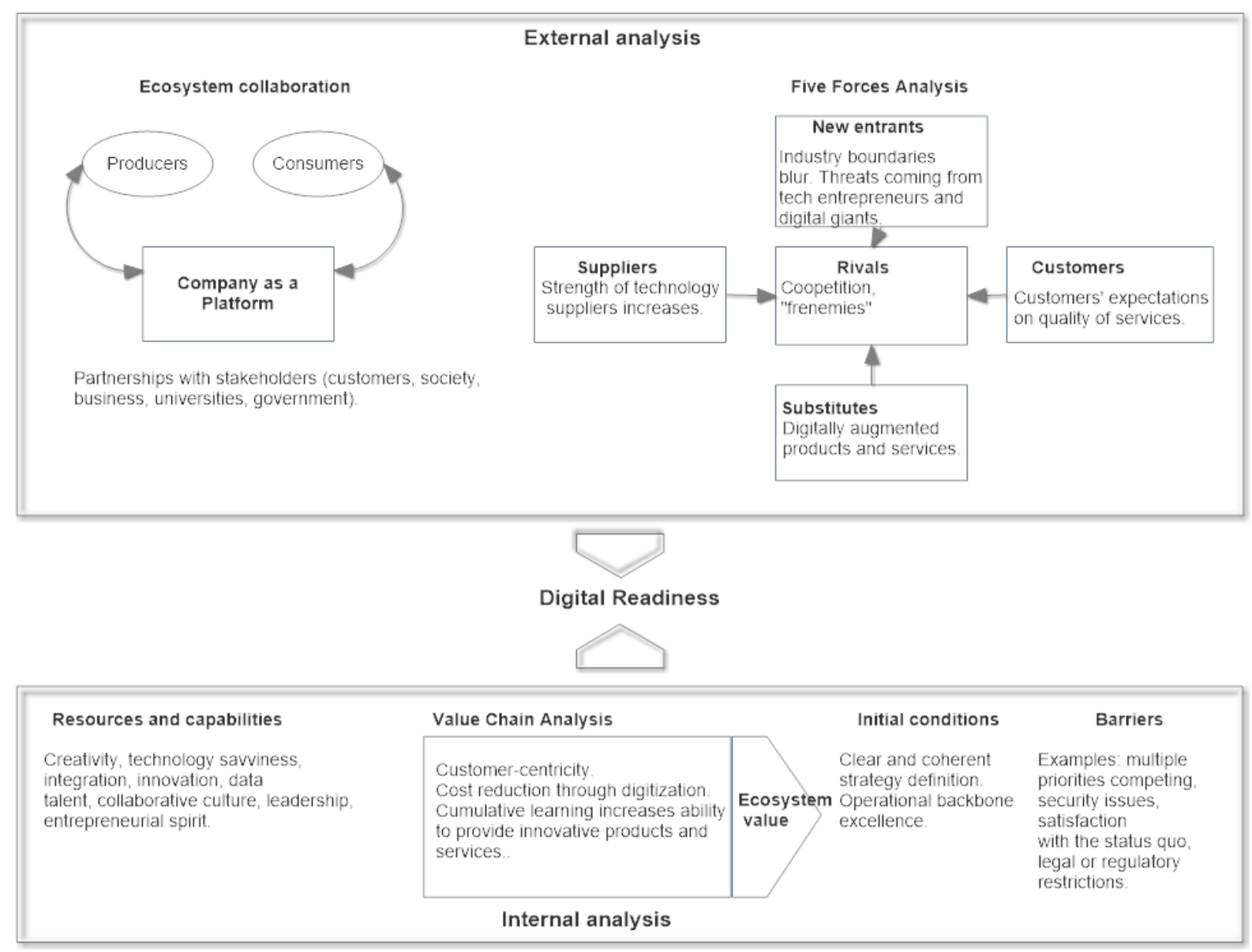

\section{Figure 2}

Private organizations digital readiness framework Source: Own elaboration.

The organization success to create value depends on a clear digital strategy definition and the ability to make it happen. In the case of Gen Tecnológico, the initiative and leadership of the owner emerges as a strong capability relevant for strategy definition and implementation. Similarly, for the case of Etman, owners' leadership is a critical factor for the company's ability to innovate and effectively exploit information technology. The relevance of having a clear and coherent strategy definition is consistent with the findings of Kane et al. (2015) and Ross et al. (2016). Exiting literature indicates that some initial conditions such as operational backbone 
maturity may have a positive influence on managerial choices and available resources. The cases corroborate this finding: excellence in operational backbone provides a sustainable advantage to Etman in developing innovative projects. This advantage can arise from commanding cost reduction (efficiency) and the ability to provide improved services based on better insights into customers' needs (differentiation). Etman's warehouse management system contributes to the reduction of costs, time and the agility of transactions. In addition, the digital catalogue project provides a platform that simplifies transactions and gives access to relevant information that adds to the excellence in service. The Value Chain Analysis framework helps to recognize the cost reduction and differentiation strategies. Similarly, customer service in Argentina Crossing is supported with a digital platform that contributes to the agility and efficiency of transactions.

Nearly every traditional business model of companies in the financial service industry is challenged by increasing digitization and whole business models become obsolete by bypassing an intermediary financial service provider in the value chain. However, in the case of Argentina Crossing, the organization's business processes require a lot of person-to-person interaction, but this is because customers value it. As observed by McAfee and Brynjolfsson (2017) it more difficult that a full digital service would replace a traditional when this offers a differential. However, as with customers will increasingly belong from the digital native generation, customers would certainly prefer more virtualized interactions. Also, for information-intensive services, the digital threat is more serious and first movers develop a learning advantage.

The cases analysis revealed some barriers to digital transformation: many priorities that compete, security concerns, satisfaction with status quo, lack of leadership, legal/regulations restrictions, and customers adaptation to digital transformation. 


\section{Conclusions and Future Research}

The paper contributes with a conceptual framework based on the literature and the analysis of cases. The case studies allow interpreting theoretical constructs for the case of small to medium size companies. These analyses provide some light and inspiration for similar companies to understand how they can transform to engage in the digital transformation. Previous researches that analyze organizational preparedness consider success stories from developed countries, established large organizations or digital giants such as Google or Amazon. Hence, this work is focused on small and medium sized established enterprises operating in a developing region where digital transformation make take place at a slower pace. One of the contributions is the analysis of enterprises with different degrees of digital exposure, the description of how context affects them and which had been the management decisions to respond to challenges derived from emerging technologies. Hence, the reader may look at Etman case, which shows how operational excellence allows the company to identify digital opportunities and to engage in ambitious projects. Interviews confirm the fact that during the company's lifetime, management has always been in charge of leaders concerned about excellence in service. Gen Tecnológico may be assimilated into the technological entrepreneur profile that has incorporated in its DNA the experimentation and eventually has the expertise to successfully accomplish potentially valuable projects. Finally, the case in the financial sector appears to be more conservative in its digital transformation journey. It is difficult to assure if it is the right decision in the long way: industry forecasts suggest that for an information-intensive service it is easier to convert to fully digital but on the other hand, the current conservative customers may be better retained with a person-to-person interaction.

To summarize, from the case studies emerge that responding to the digital challenge involves creating new business models, redefining relationships among companies, finding new ways to innovate, leveraging social tools to engage with customers, and building visionary leaders. The findings coincide with those reported in the literature and it appears that the geographical region of selected cases does not impose different barriers, or particular required resources or capabilities. 
The article is no without its limitations. The empirical analysis is limited to three cases and it must be acknowledged that conclusions may not be generalized. Future work can certainly be directed at developing a similar work for other forms of research methodology.

A final thought is that having some technological initiatives do not constitute a digital strategy. When talked with some interviewees about what they mean by digital, some view it as the digitization of functional processes. The lack of a clear understanding of digital transformation may prevent companies from learning how to compete and eventually their business models will not remain economically viable.

\section{References}

Argentina Autoblog. (2015, April 8). Autoblog.com.ar. Retrieved from Leo Valente convirtió su primer auto híbrido en Argentina: http://autoblog.com.ar/2015/04/08/leo-valente-convirtio-su-primer-auto-hibrido-enargentina/

Argentina Crossing S.A. (2017, August 8). Argentina Crossing. Retrieved from http://www.argentinacrossing.com.ar/

Bengtsson, M., \& Raza-Ullah, T. (2016). A systematic review of research on coopetition: Toward a multilevel understanding. Industrial Marketing Management, 57, 23-39.

Bennis, W. (2013). Leadership in a Digital World: Embracing Transparency and Adaptive Capacity. MIS Quarterly, 37(2), 635-636.

Berenstein, M. (2014, March 28). E-news. Retrieved from SocialPOS, ganador de ImpacTec 2014: http://emprendedoresnews.com/varios/socialpos-ganador-deimpactec-2014.html

Bradshaw, T., \& Palmer, M. (2010, 2 24). Financial Times. Retrieved from Ad world keen to find new "frenemy": https://www.ft.com/content/ca5c820a-2177-11df830e-00144feab49a

Conforto, E., Salum, F., Amaral, D., da Silva, S., \& Magnanini de Almeida, L. (2014). Can Agile Project Management be Adopted by Industries Other than Software Development? Project Management Journal, 45(3), 21-34.

Davenport, T., Barth, P., \& Bean, R. (2012). How "Big Data" Is Different. MIT Sloan Management Review, 22-24. 
Diario La Nueva S.R.L. (2015, March 15). La Nueva. Retrieved from El bahiense Leonardo Valente clasificó a la final de un certamen de empresas: http://www.lanueva.com/la-ciudad/803543/el-bahiense-leonardo-valente-clasificoa-la-final-de-un-certamen-de-empresas.html

Eisenhardt, K. (1989). Building theories from case study research. Academy of Management Review, 14(4), 532-550.

Etman Distribuidor Nacionall de Autopartes. (2017). Etman Distribuidor Nacional de Autopartes. Retrieved September 11, 2017, from Info Técnica: http://www.portaletman.com.ar/index.php/info-tecnica

Gen Tecnológico. (2017, August 3). Gen Tecnológico. Retrieved from tech as a Service S.R.L.: www.gentecnologico.com.ar

Hannan, M., \& Freeman, J. (1977). The population ecology of organizations. American Journal of Sociology, 82(5), 929-964.

Karhu, K., Botero, A., Vihavainen, S., Tang, T., \& Hämäläinen, M. (2011). A Digital Ecosystem for Co-Creating Business with People. Journal of Emerging Technologies in Web Intelligence, 3(3), 197-205.

Klotz, F. (August de 2016). Navigating the Leadership Challenges of Innovation Ecosystems. MIT SMR Frontiers, 1-5.

La Nación. (2014, April 6). La Nación. Retrieved from SocialPOS, una herramienta para beneficiar a los comercios barriales: http://www.lanacion.com.ar/1678386socialpos-una-herramienta-para-beneficiar-a-los-comercios-barriales

La Nación. (2015, January 2). La Nación. Retrieved from Leonardo Valente, el argentino que sueña con crear autos híbridos en todo el país: http://www.lanacion.com.ar/1756795-leonardo-valente-argentino-innovadorsilicon-valley-autos-hibridos

Libert, B., Beck, M., \& Wind, J. (2016). The Network Imperative. How to survive and grow in the age of digital business models. Boston: Harvard Business Review Press.

McAfee, A., \& Brynjolfsson, E. (2012). Big Data: The Management Revolution. Harvard Business Review, 10, 60-79.

McAfee, A., \& Brynjolfsson, E. (2017). Machine, Platform, Crowd. Harnessing our digital future. New York: W. W. Norton \& Company Ltd.

Mundo Aftermarket. (2017, January 23). Mundo Aftermarket. Retrieved September 11, 2017, from Nos gusta: Etman presenta su nuevo catálogo digital: http://mundoaftermarket.com/?Nos_gusta\%3A_Etman_presenta_su_nuevo_catal ogo_digital\&page=ampliada\&id=9777\&_s=\&_page=buscar 
Mundo Aftermarket. (2017, July 21). Mundo Aftermarket. Retrieved September 11, 2017, from La eficiencia ante todo: Etman muestra su Sistema Automatizado de Despachos:

http://mundoaftermarket.com/?La_eficiencia_ante_todo\%3A_Etman_muestra_su _Sistema_Automatizado_de_Despachos\&page=ampliada\&id=9789\&_s=\&_page $=$ buscar

Penrose, E. (1959). The Theory of the Growth of the Firm. New York: Wiley.

Polo Tecnologico del Sur. (2018, 1 22). Polo Tecnologico del Sur. Retrieved from http://ptbb.org.ar/

Porter, M., \& Heppelmann, J. (2014). How Smart, Connected Products Are Transforming Competition. Harvard Business Review, 4-23.

Porter, M., \& Heppelmann, J. (2015). How Smart, Connected Products are Transforming Companies. Harvard Business Review, 1-19.

Ross, J., Sebastian, I., \& Beath, C. (2016). How to Develop a Great Digital Strategy. MIT Sloan Management Review.

Sánchez, M. (2017). A Framework to Assess Organizational Readiness for the Digital Transformation. Dimensión Empresarial, 15(2), 27-40.

Slama, D., Puhlmann, F., Morrish, J., \& Bhatnagar, R. (2015). Enterprise loT. O'Reilly Media.

Stacey, R. (1995). The science of complexity: an alternative perspective for strategic change processes. Strategic Management Journal, 16(6), 477-495.

Teece, D., Pisano, G., \& Shuen, A. (1997). Dynamic capabilities and strategic management. Strategic Management Journal, 18(7), 509-533.

Van Alstyne, M., Parker, G., \& Choudary, P. (April de 2016). Pipelines, Platforms, and the New Rules of Strategy. Harvard Business Review, 54-60,62.

Venkatraman, V. (2017). The Digital Matrix. New Rules for Business Transformation Through Technology. Canada: LifeTree Media Ltd.

Weill, P., \& Woerner, S. (2015). Thriving in an increasingly digital ecosystem. MIT Sloan Management Review, 56(4), 27-34.

\section{Appendix}

The appendix includes a summary of responses. References: $G$ (Gen Tecnológico), E (Etman), and A (Argentina Crossing S.A.).

\section{Strategy definition}


1. To what extent your value proposition depends on new ways of collaboration with stakeholders?

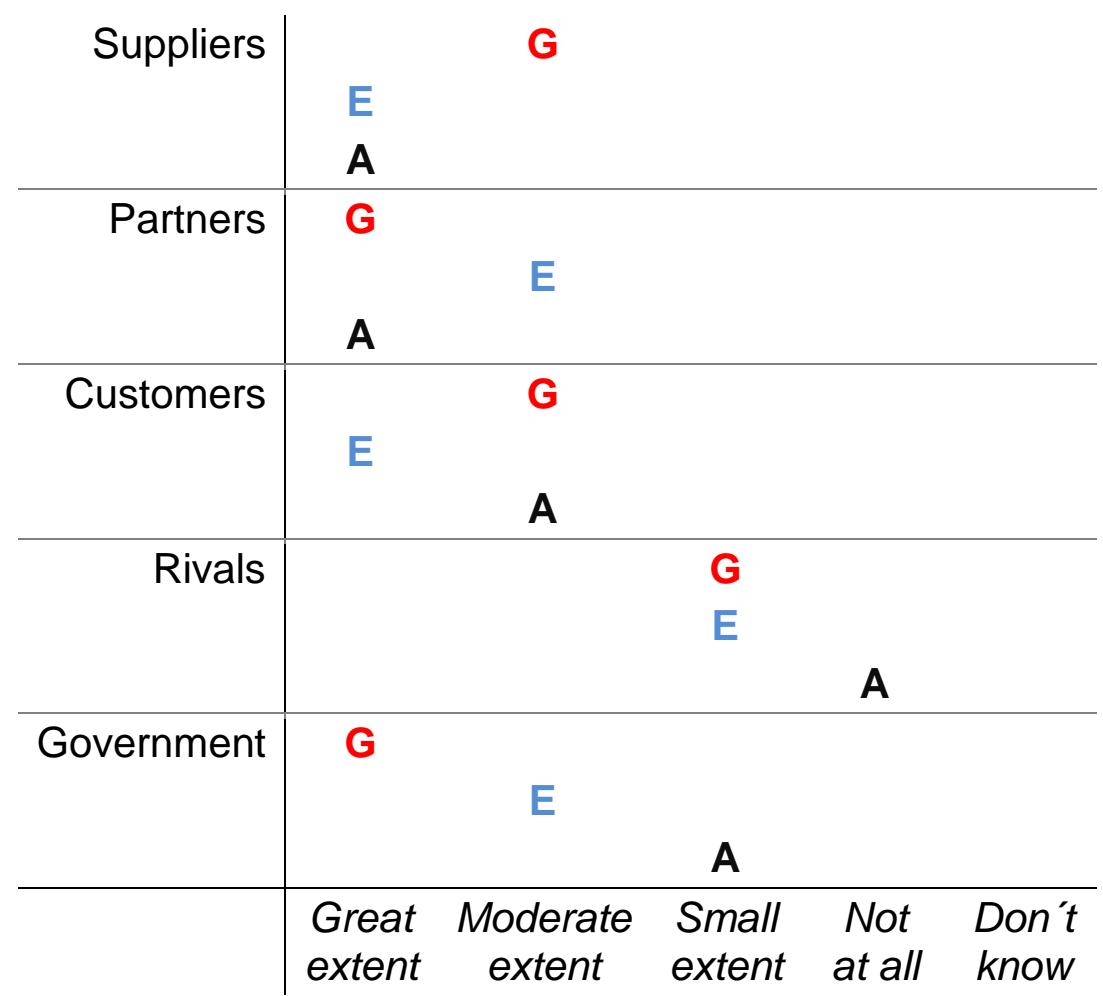

2. To what extent do you agree that the following are part of your organization's strategy?

\begin{tabular}{r|ccc}
$\begin{array}{r}\text { Improve customer } \\
\text { experience }\end{array}$ & E & & \\
& A & & \\
\hline Innovation based on & G & & \\
data analysis & E & & \\
& A & & \\
\hline Data driven decision & & G & \\
making & E & & \\
& A & & \\
\hline Process transformation & G & & \\
& E & & Strongly Don't \\
& A & & disagree know
\end{tabular}


3. To what extent do you think your organization knows customers' needs?

G

\begin{tabular}{cccc} 
A & & & \\
\hline Great & $\begin{array}{c}\text { Moderate } \\
\text { extent }\end{array}$ & $\begin{array}{c}\text { Small } \\
\text { extent }\end{array}$ Not at all & $\begin{array}{c}\text { Don't } \\
\text { know }\end{array}$
\end{tabular}

4. Who has the responsibility to define the digital strategy? (multiple selections)

\begin{tabular}{r|l} 
General Director & G, E \\
Middle management & E, A \\
Operations & \\
Collaboratively defined & A \\
Employees & G \\
Supplier &
\end{tabular}

5. Which are the drivers to define an Information Technology initiative? (multiple selections)

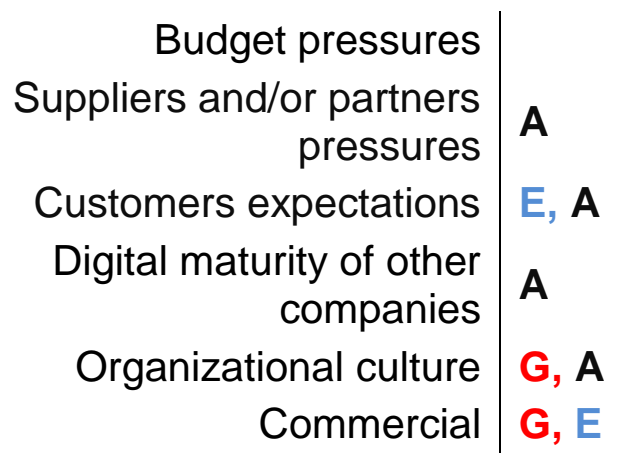

6. Consider one of your most demanded services. To what extent is this service ...

\begin{tabular}{r|cc}
$\begin{array}{r}\text { Ordered } \\
\text { digitally? }\end{array}$ & G & E \\
& A & \\
Delivered & G & \\
digitally? & A & \\
\hline $\begin{array}{r}\text { Augmented (or } \\
\text { can be) with }\end{array}$ & E & \\
valuable & G & \\
information? & G \\
\hline Augmented & G & \\
with external & E & \\
data? & A & \\
& G
\end{tabular}




\begin{tabular}{r|rrr}
$\begin{array}{r}\text { Going to be } \\
\text { delivered } \\
\text { digitally in five } \\
\text { years? }\end{array}$ & E & A \\
\hline & $\begin{array}{r}\text { Great } \\
\text { extent }\end{array}$ & $\begin{array}{c}\text { Moderate Small } \\
\text { extent }\end{array}$ extent Not at all & $\begin{array}{c}\text { Don't } \\
\text { know }\end{array}$
\end{tabular}

\section{Resources and capabilities}

7. My organization ...

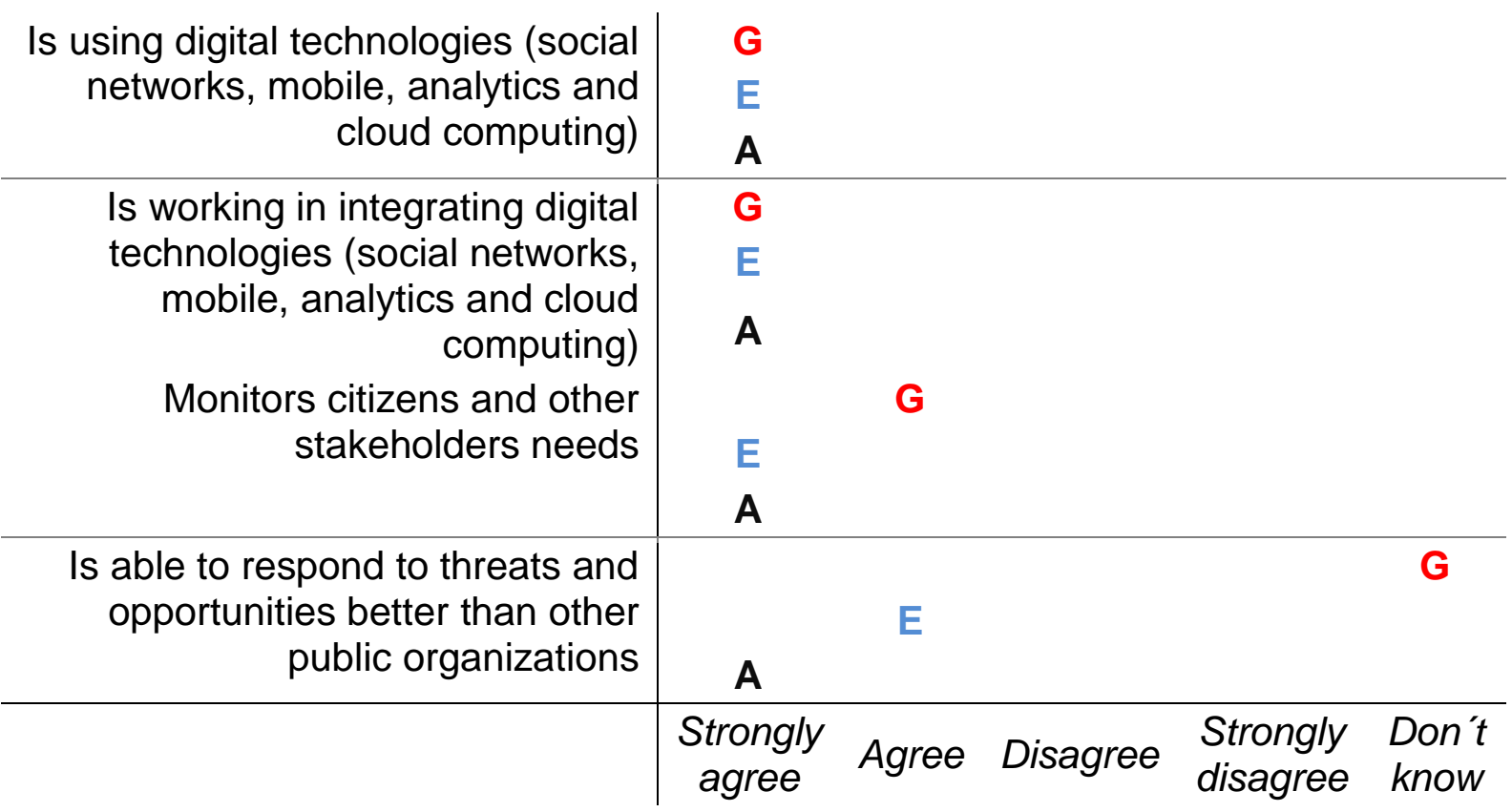

\section{Data management}

8. In my organization ...

Our senior executives regularly consider the opportunities that data analytics (data mining, OLAP,

Big Data) might bring to our business

We integrate data from multiple internal sources into a data warehouse for easy access

We integrate external data with internal to facilitate high-value analysis of our business environment
G

E

A

G

E

A

G

E

A 


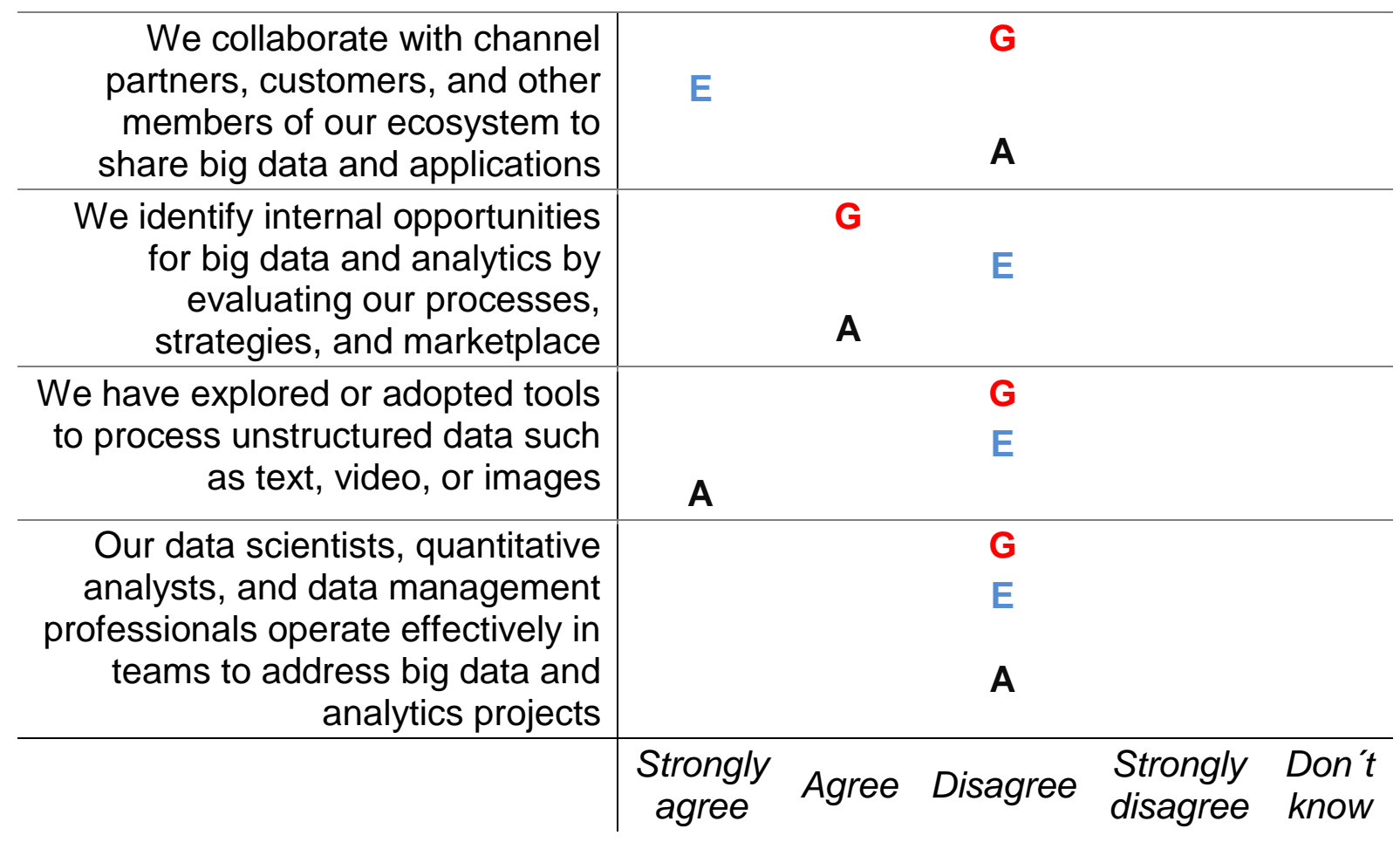

\section{Project management}

9. How project success is defined?

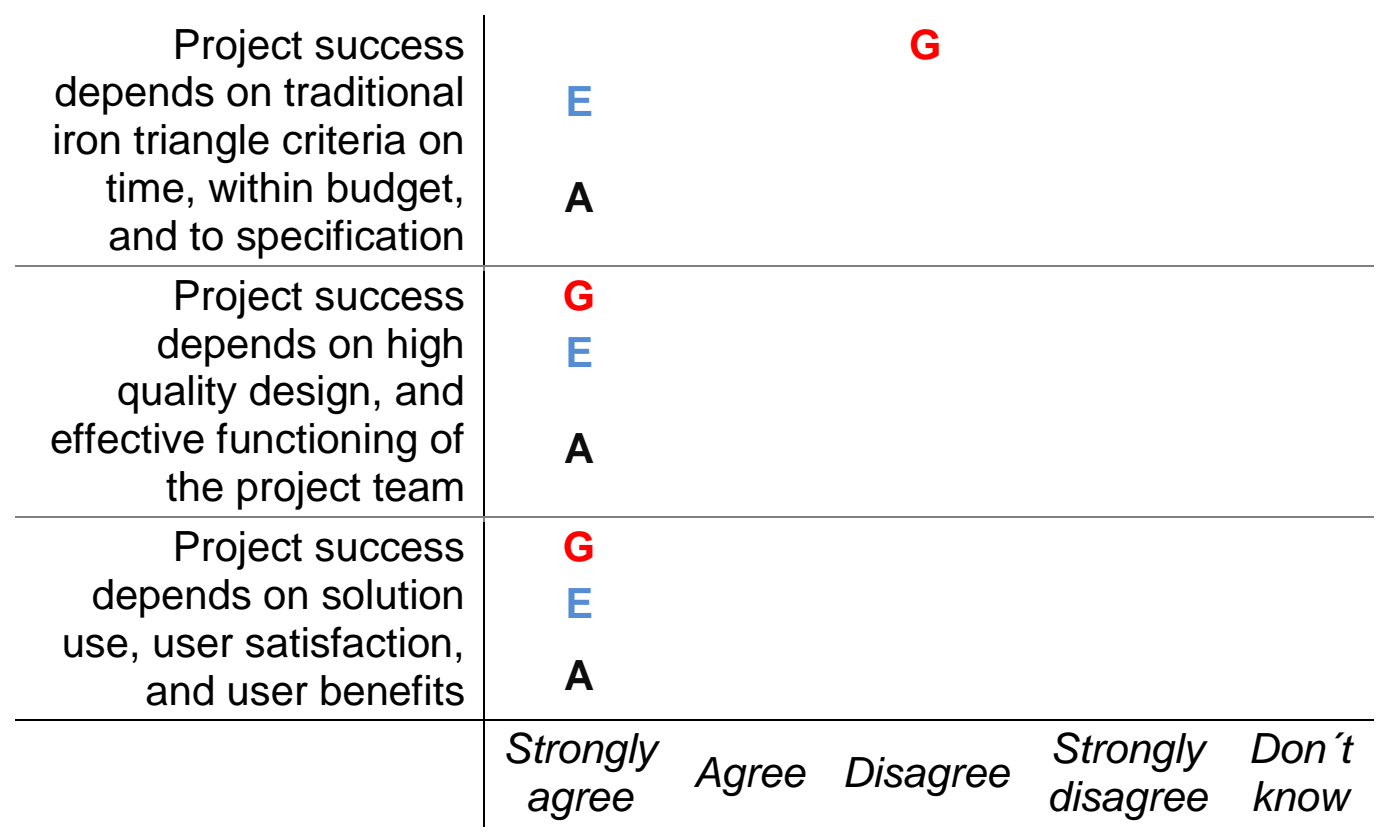

10. Stakeholder involvement: (select an option)

$$
\begin{array}{r}
\text { Not involved } \\
\text { Involved without influence } \\
\text { Involved with influence }
\end{array} \text { G, E, A }
$$




\section{Don't know}

11. Multidisciplinary project teams: (select an option)

$$
\begin{array}{r|r}
\text { Not multi-functional } & \\
\text { Some key departments } & \text { G, E, A } \\
\text { Most departments } & \\
\text { Don't know } &
\end{array}
$$

12. Project management responsibility: (multiple selections)

$$
\left.\begin{array}{r|r}
\text { Created by a department or Project } \\
\text { Management Office } \\
\text { Created by the project manager } \\
\text { Created collaboratively } \\
\text { Don't know }
\end{array}\right) \text { G, E, A }
$$

\section{Barriers to adopt digital technologies}

13. Which barriers are impeding your organization to adopt or develop digital technologies? (select up to three)

Lack of organizational strategy

Lack of collaborative culture Lack of leadership Satisfaction with status quo Political context Legal/regulations restrictions Insufficient technology infrastructure

Employees lack of ability to use digital technologies (cloud, social, mobile, analytics)

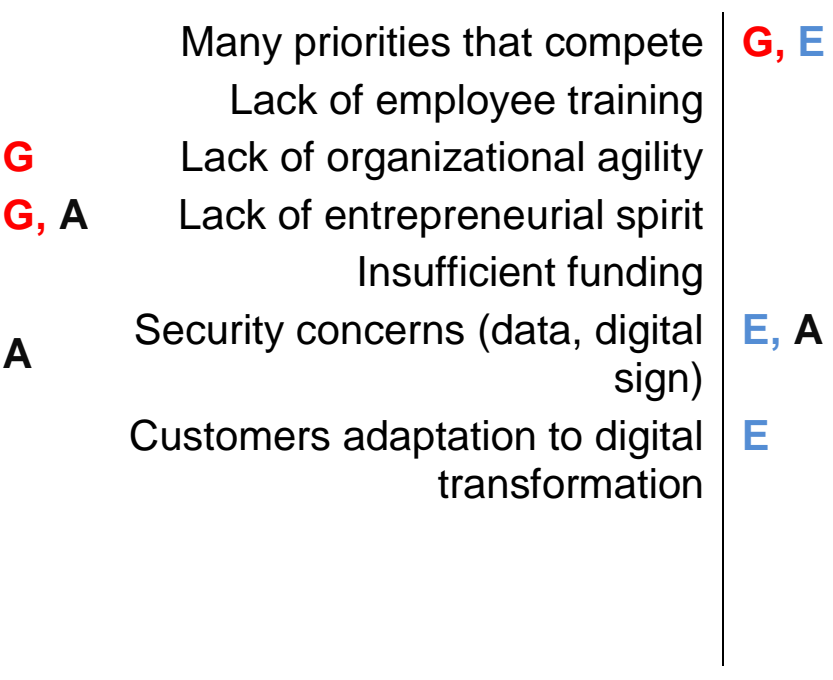

